\title{
MENINGKATKAN KINERJA PEGAWAI NEGERI SIPIL (PNS) MELALUI PENGELOLAAN KECERDASAN DAN SIKAP ETIS
}

\author{
Dicky Adhinurwanto; Indarto \\ indarto@usm.ac.id \\ Program Studi Magister Manajemen, Universitas Semarang, Semarang, Indonesia
}

\begin{tabular}{l} 
Info Artikel \\
\hline Sejarah Artikel: \\
Diterima \\
Disetujui \\
Dipublikasikan \\
\hline Keywords: \\
emotional \\
intelligence; \\
intellectual; \\
spiritual; \\
ethicalattitude; \\
performance
\end{tabular}

Abstrak

. Faktual problem yang saat ini sedang dihadapi oleh PNS adalah sorotan negatif akibat kemerosotan mental dan moral yang ditunjukkan dalam melaksanakan tugas pelayanan, mengemukanya praktek KKN (Kolusi, Korupsi dan Nepotisme), menguaknya issue amoral yang telah melibatkan penyelenggara negara, juga terungkap perilaku kekerasan dalam rumah tangga yang dilakukan oleh anggota PNS adalah fakta yang tidak dapat dipungkiri. Mengacu pada temuan faktual problem yang ada maka masalah penelitian yang dirumuskan adalah "Bagaimana meningkatkan sikap etis dan kinerja PNS di lingkungan kantor Setda Provinsi Jawa Tengah?”.

Dengan menggunakan data yang diperoleh melalui kuesioner yang disebarkan kepada responden pegawai Biro Umum di Kantor Setda Provinsi Jawa Tengah, penelitian ini menguji pengaruh kecerdasan emosional, kecerdasan intelektual, dan kecerdasan spiritual terhadap sikap etis dan kinerja. Pengujian pengaruh antar variabel dilakukan dengan menggunakan Uji Regresi Berganda.

Hasil pengujian regresi berganda menunjukkan bahwa kecerdasan emosional, kecerdasan intelektual, dan kecerdasan spiritual terbukti berpengaruh positif signifikan terhadap sikap etis. Hasil penelitian ini juga menunjukkan bahwa kecerdasan emosional, kecerdasan intelektual, kecerdasan spiritual serta sikap etis terbukti memiliki pengaruh signifikan terhadap kinerja pegawai.

\section{IMPROVE THE PERFORMANCE OF CIVIL SERVANTS (PNS) THROUGH MANAGEMENT OF INTELLIGENCE AND ETHICAL ATTITUDES}

\section{Abstract}

Factual problems currently being faced by civil servants is negative spotlight due to mental deterioration and moral demonstrated in carrying out the ministry, collusion, corruption and nepotism, to reveal issue amoral that has involved state officials, also 
revealed violent behavior in the home the stairs were made by members of civil servants is a fact that can not be denied. Referring to the factual findings of the problems formulated the research problem is "How to improve ethical attitudes and performance of civil servants in the Central Java Provincial Secretariat office?".

By using the data obtained through a questionnaire distributed to respondents employee in the Office of General Bureau Secretariat of Central Java province, this study examines the effect of emotional intelligence, intellectual, and spiritual intelligence of the ethical attitude and performance. Testing the influence between variables is done by using multiple regression test.

The test results of multiple regression showed that emotional intelligence, intellectual, and spiritual intelligence proved significant positive effect on the ethical attitudes. The results also indicate that emotional intelligence, intellectual, spiritual intelligence and ethical attitude shown to have a significant influence on employee performance. 


\section{PENDAHULUAN.}

Pembinaan Mental dan Moral Pegawai Negeri Sipil (PNS) merupakan bagian integral dari pembinaan Sumber Daya Manusia (SDM) aparatur pemerintah secara keseluruhan. Pentingnya pembinaan PNS adalah karena fungsinya yang sentral dalam arti sangat menentukan dalam pembangunan bangsa dan negara. PNS yang memiliki mental dan moral yang baik dapat mendorong bagi terwujudnya kepemerintahan yang baik (good governance) dan pemerintah yang bersih (clean government).Sebagai bagian integral dari pengembangan Sumber Daya Manusia (SDM) aparatur pemerintah, pendidikan dan pelatihan (DIKLAT) memiliki peran penting dan strategis dalam pembangunan bangsa. Menyadari arti peran tersebut, maka upaya yang terus menerus untuk melakukan pembinaan terhadap Pegawai Negeri Sipil (PNS) harus dilakukan.

Mengingat posisi PNS itu merupakan tulang punggung penyelenggara Negara yang belakangan ini banyak mendapat sorotan negatif akibat kemerosotan mental dan moral yang ditunjukkan dalam melaksanakan tugas pelayanan, mengemukanya praktek KKN (Kolusi, Korupsi dan Nepotisme), menguaknya issue amoral yang telah melibatkan penyelenggara negara, juga terungkap perilaku kekerasan dalam rumah tangga yang dilakukan oleh anggota PNS adalah fakta yang tidak dapat dipungkiri.

Berbagai penelitian tentang etika memberikanbukti empiris mengenai faktor-faktoryang mempengaruhi sikap dan perilaku etis seseorang yang dapat dikelompokkanke dalam tiga aspek, yaitu: 1) Aspekindividual; 2) Aspek organisasional;dan 3) Aspek lingkungan. Penelitiantentang etika yang berfokus pada aspek individualmenunjukkan berbagaifaktor yang mempengaruhi sikap danperilaku etis seseorang antara lain: a)Religiusitas (Clark \& Dawson, 1996; Maryani \& Ludigdo, 2001; Weaver \&Agle 2002), b) Kecerdasan emosional Ludigdo, 2001; Baihaqi, 2002), c)Gender (Ruegger \& King, 1992; Reiss\& Mitra, 1998; Abdulrahim, 1999;Chrismastuti \& Purnamasari, 2004), d)Suasana etis (ethical climate) individu(Wimbush, Shepard \& Markham,1997), e) Sifat-sifat personal (Verbeke,Ouwerkerk \& Peelen, 1996;Chrismastuti \& Purnamasari, 2004), dan f) Kepercayaan bahwa orang lainlebih tidak etis (Tyson, 1992).

Penekanan pada penelitian adalah pada dimensi kecerdasan emosional, intelektual, dan spiritual. Menurut Ginanjar (2007) menyatakan bahwa ketiga bentuk kecerdasan di atas sangat penting dan harus dikembangkan dalam kehidupan seseorang. Hal ini disebabkan karena kecerdasan intelektual dibutuhkan untuk mengatasi masalah-masalah yang kognitif, kecerdasan emosional diperlukan untuk mengatasi masalah afektif, dan kecerdasan spiritual digunakan untuk mengatasi masalah bermaknaan dalam menjalani kehidupan.

Penelitian ini masih menarik untuk diteliti mengingat masih adanya perbedaan hasil-hasil penelitian terdahulu mengenai variabel-variabel yang mempengaruhi sikap etis seorang pegawai. Pengaruh kecerdasan emosional terhadap sikap etis telah diteliti oleh Ludigdo (1999), Maryani dan Ludigdo (2001), Jamaluddin dan Indriasari (2012), Lucyanda dan Eko (2013) yang hasilnya menunjukkan bahwa kecerdasan emosional berpengaruh positif signifikan terhadap sikap etis sedangkan pada penelitian Tikollah, dkk (2006), Ika 
(2011), menunjukkan bahwa kecerdasan emosional berpengaruh tidak signifikan terhadap sikap etis.

Pada penelitian yang dilakukan oleh Tikollah, dkk (2006), Maryani dan Ludigdo (2001), Jamaluddin dan Indriasari (2012) menunjukkan bahwa kecerdasan intelektual terbukti berpengaruh positif signifikan terhadap sikap etis sedangkan penelitian Lucyanda dan Eko (2013) menunjukkan hasil yang berbeda dimana kecerdasan intelektual terbukti tidak berpengaruh signifikan terhadap sikap etis.

Penelitian Ludigdo (1999), Maryani dan Ludigdo (2001), Ika (2011), Jamaluddin dan Indriasari (2012), Ramly, Chai dan Lung (2008) membuktikan adanya pengaruh positif dan signifikan dari kecerdasan spiritual terhadap sikap etis sedangkan penelitian Tikollah, dkk (2006) dan Lucyanda dan Eko (2013) menunjukkan bahwa kecerdasan spiritual berpengaruh tidak signifikan terhadap sikap etis.

Mengacu pada research gap yang ada maka masalah penelitian yang dirumuskan adalah "Bagaimana meningkatkan sikap etis dan kinerja PNS di lingkungan kantor Setda Provinsi Jawa Tengah?"

\section{TELAAH PUSTAKA}

\section{Pengaruh Kecerdasan Emosional terhadap Sikap Etis}

Kecerdasan emosional berkaitan dengan kemampuan untuk mengetahui perasaan sendiri dan perasaan orang lain serta menggunakan perasaan tersebut untuk menuntun pikiran dan perilaku seseorang (Salovey dan Mayer dalam Svyantek, 2003).

Penelitian Ludigdo (1999) menyatakan bahwa masalah sikap etis bukanlah sekedar masalah rasionalitas (kecerdasan intelektual) namun terlebih dari itu juga menyangkut masalah dimensi emosional manusia. Demikian pula dengan penelitian Jamaluddin dan Indriasari (2012), Lucyanda dan Eko (2013) juga membuktikan pengaruh positif dan signifikan dari kecerdasan emosional terhadap sikap etis. Sedangkan pada Penelitian yang dilakukan oleh Tikollah, dkk (2006), Ika (2011), menunjukkan bahwa kecerdasan emosional berpengaruh tidak signifikan terhadap sikap etis.

Berdasarkan uraian di atas maka hipotesis yang dikembangkan adalah:

H1: Kecerdasan emosional berpengaruh positif terhadap sikap etis

\section{Pengaruh Kecerdasan Intelektual terhadap Sikap Etis}

Saifer dan Hoffnung (dalam Desmita, 2006) mendefinisikan kecerdasanintelektual mengacu pada kemampuanumum yaitu belajar dari pengalaman danmengacu pada kemampuan untukmengkritik dan berfikir abstrak. MenurutElhamidi (2009) kecerdasan intelektualadalah kecerdasan yang menuntutpemberdayaan otak, hati, jasmani, danpengaktifan manusia untuk berinteraksisecara fungsional dengan yang lain. 
Pada Penelitian yang dilakukan oleh Tikollah, dkk (2006), Maryani dan Ludigdo (2001), Jamaluddin dan Indriasari (2012) menunjukkan bahwa kecerdasan intelektual terbukti berpengaruh positif signifikan terhadap sikap etis. Sedangkan pada penelitian Lucyanda dan Eko (2013) yang juga menguji pengaruh kecerdasan intelektual terhadap sikap etis menunjukkan hasil yang berbeda dimana kecerdasan intelektual terbukti tidak berpengaruh signifikan terhadap sikap etis.

Berdasarkan uraian di atas maka hipotesis yang dikembangkan adalah:

H2: Kecerdasan intelektual berpengaruh positif terhadap sikap etis

\section{Pengaruh Kecerdasan Spiritual terhadap Sikap Etis}

Kecerdasan spiritual berkaitan dengan kecerdasan yang digunakan untuk menghadapi dan memecahkan persoalan makna dan nilai yang menempatkan perilaku dan hidup manusia dalam konteks yang lebih luas dan kaya yang memungkinkan seseorang untuk menyatukan hal-hal yang bersifat intrapersonal dan interpersonal serta menjembatani kesenjangan antara diri sendiri dan orang lain (Zohar dan Marshall, 2002).

Penelitian Ludigdo (1999) menyatakan bahwa masalah sikap etis bukanlah sekedar masalah rasionalitas (kecerdasan intelektual) namun terlebih dari itu juga menyangkut masalah dimensi spiritual manusia. Demikian pula dengan penelitian Maryani dan Ludigdo (2001), Ika (2011), Jamaluddin dan Indriasari (2012), Ramly, Chai dan Lung (2008) juga membuktikan pengaruh positif dan signifikan dari kecerdasan spiritual terhadap sikap etis. Sedangkan pada penelitian yang dilakukan oleh Tikollah, dkk (2006) dan Lucyanda dan Eko (2013) menunjukkan bahwa kecerdasan spiritual berpengaruh tidak signifikan terhadap sikap etis.

Berdasarkan uraian di atas maka hipotesis yang dikembangkan adalah:

H3: Kecerdasan spiritual berpengaruh positif terhadap sikap etis

\section{Pengaruh Sikap Etis terhadap Kinerja}

Etika profesi berfungsi sebagai pedoman dalam pelaksanaan tugas pemeriksaan yang dilaksanakan oleh auditor. Behn et al (1997) dalam Widagdo et al (2002) mengembangkan atribut kinerja. Bagaimanapun situasi kontekstual memerlukan perhatian dalam berbagai aspek pengembangan profesionalisme termasuk di dalamnya melalui suatu penelitian. Kode etik profesi merupakan kaidah-kaidah yang menjadi landasan bagi eksistensi profesi dan sebagai dasar terbentuknya kepercayaan masyarakat karena dengan mematuhi kode etik, seorang pegawai diharapkan dapat menghasilkan kualitas kinerja yang paling baik bagi masyarakat, sehingga jika semakin tinggi tingkat ketaatan pegawai terhadap kode etik profesinya, maka kinerja yang akan dicapai akan semakin baik pula. Penelitian yang dilakukan oleh Choriyah (2013) pada variabel sikap etis dan kinerja menunjukkan bahwa sikap etis terbukti berpengaruh positif dan signifikan terhadap kinerja.

Berdasarkan uraian di atas maka hipotesis yang dikembangkan adalah:

H4: Sikap etis berpengaruh positif terhadap kinerja 


\section{Pengaruh Kecerdasan Emosional terhadap Kinerja}

Goleman (2005) menyatakan dalam bukunya bahwa untuk mencapai kesuksesan dalam dunia kerja bukan hanya cognitive intelligence saja yang dibutuhkan tetapi juga emotional intelligence. Purba (1999) berpendapat bahwa kecerdasan emosi adalah kemampuan di bidang emosi yaitu kesanggupan menghadapi frustasi, kemampuan mengendalikan emosi, semangat optimisme, dan kemampuan menjalin hubungan dengan orang lain atau empati. Hal tersebut seperti yang dikemukakan Patton (1998 dalam Fabiola, 2005) bahwa penggunaan emosi yang efektif akan dapat mencapai tujuan dalam membangun hubungan yang produktif dalam meraih keberhasilan kerja.

Kinerja tidak hanya dilihat oleh faktor intelektualnya saja tetapi juga ditentukan oleh faktor emosinya. Seseorang yang dapat mengontrol emosinya dengan baik maka akan dapat menghasilkan kinerja yang baik pula. Hal ini sesuai dengan yang diungkapkan oleh Meyer (2004 dalam Fabiola, 2005) bahwa kecerdasan emosi merupakan faktor yang sama pentingnya dengan kombinasi kemampuan teknis dan analisis untuk menghasilkan kinerja yang optimal. Salah satu aspek dalam kecerdasan emosi adalah motivasi.

Penelitian yang dilakukan oleh Choriyah (2013) pada variabel kecerdasan emosional dan kinerja menunjukkan bahwa kecerdasan emosional memiliki pengaruh positif dan signifikan terhadap kinerja. Demikian pula dengan penelitian yang telah dilakukan oleh Agustian (2001) yang menunjukkan bahwa keberadaan kecerdasan emosional yang baik akan membuat seorang karyawan menampilkan kinerja dan hasil kerja yang baik. Penelitian lainnya yang pernah dilakukan oleh Boyatzis (1999 dalam Fabiola, 2005) dan Chermiss (1998 dalam Fabiola, 2005) terhadap beberapa subjek penelitian dalam beberapa perusahaan maka hasil yang didapat menunjukan bahwa karyawan yang memiliki skor kecerdasan emosi yang tinggi akan menghasilkan kinerja yang lebih baik yang dapat dilihat dari bagaimana kualitas dan kuantitas yang diberikan karyawan tersebut terhadap perusahaan. Chermiss juga mengungkapkan bahwa walaupun sesorang tersebut memiliki kinerja yang cukup baik tapi apabila dia memiliki sifat yang tertutup dan tidak berinteraksi dengan orang lain secara baik maka kinerjanya tidak akan dapat berkembang. Demikian pula studi yang telah dilakukan oleh Maryani dan Ludigdo (2001) menunjukkan bahwa kecerdasan emosional terbukti berpengaruh positif signifikan terhadap kinerja.

Berdasarkan uraian di atas maka hipotesis yang dikembangkan adalah:

H5: Kecerdasan emosional berpengaruh positif terhadap kinerja

\section{Pengaruh Kecerdasan Intelektual terhadap Kinerja}

Karir dalam dunia kerja erat kaitannya dengan kecerdasan intelektual yang dimiliki oleh seseorang. Seorang pekerja yang memiliki IQ tinggi diharapkan dapat menghasilkan kinerja yang lebih baik dibandingkan mereka yang memiliki IQ lebih rendah. Hal tersebut karena mereka yang memiliki IQ tinggi lebih mudah menyerap ilmu yang diberikan sehingga kemampuannya dalam memecahkan masalah yang berkaitan dengan pekerjaannya akan lebih baik (Eysenck,1981 dalam Fabiola 2005). Gordon (2004) mengungkapkan bahwa perbaikan kemampuan kognitif adalah cara terbaik untuk meningkatkan kinerja. 
Kemampuan kognitif dalam hal ini kecerdasan intelektual merupakan alat peramal yang paling baik untuk melihat kinerja sesorang di masa yang akan datang (Hunter, 1996 dalam Fabiola, 2005).

Keseimbangan yang baik antara IQ dan EQ harus dapat dicapai. Orang yang memiliki EQ yang baik tanpa ditunjang dengan IQ yang baik pula belum tentu dapat berhasil dalam pekerjaannya. Hal ini karena IQ masih memegang peranan yang penting dalam kinerja seseorang, sehingga keberadaan IQ tidak boleh dihilangkan begitu saja (Carusso, 1999).

Penelitian yang dilakukan oleh Wiramiharja (2003) menemukan bahwa kecerdasan yang lebih bersifat kognitif berpengaruh signifikan terhadap kinerja karyawan. Wiramiharja juga menyebutkan bahwa prestasi kerja yang dimiliki oleh seseorang akan membawanya pada hasil yang lebih memuaskan untuk dapat meningkatkan kinerjanya. Dalam penelitian tersebut diperoleh hasil bahwa kecerdasan intelektual memberikan kontribusi $30 \%$ dalam pencapaian prestasi kerja dan kinerja seseorang.

Penelitian Moustafa dan Miller (2003) juga menunjukan hasil yang sama pula. Mereka meneliti tentang validitas tes skor kemampuan kognitif pada proses seleksi karyawan. Tes inteligensi merupakan alat yang tepat dalam melakukan seleksi terhadap karyawan, sehingga tes tersebut dapat memberikan keputusan bagi manajer untuk mendapatkan orang yang tepat dalam pemilihan karyawan yang dibutuhkan. Hasil penelitian menunjukkan bahwa seorang karyawan yang mendapatkan skor tes IQ yang tinggi pada saat seleksi ternyata menghasilkan kinerja yang lebih baik, terutama apabila dalam masa-masa tugasnya tersebut sering mendapatkan pengetahuan dan keterampilan baru dari pelatihan yang dilakukan. Pada penelitian Choriyah (2013) dan Maryani dan Ludigdo (2001) yang menguji pengaruh kecerdasan intelektual dan kinerja pegawai juga menunjukkan bahwa kecerdasan intelektual memiliki pengaruh positif dan signifikan terhadap kinerja.

Berdasarkan uraian di atas maka hipotesis yang dikembangkan adalah:

H6: Kecerdasan intelektual berpengaruh positif terhadap kinerja

\section{Pengaruh Kecerdasan Spiritual terhadap Kinerja}

Kecerdasan spiritual merupakan perasaan terhubungkan dengan diri sendiri, orang lain dan alam semesta secara utuh. Pada saat orang bekerja, maka ia dituntut untuk mengarahkan intelektualnya, tetapai banyak hal yang membuat seseorang senang dengan pekerjaannya.

Seorang pegawai dapat menunjukkan kinerja yang optimal apabila ia sendiri mendapatkan kesempatan untuk mengekspresikan seluruh potensi dirinya sebagai manusia. Hal tersebut akan dapat muncul apabila seseorang dapat memaknai setiap pekerjaannya dan dapt menyelaraskan antara emosi, perasaan dan otak. Kecerdasan spiritual mengajarkan orang untuk mengekspresikan dan memberi makna pada setiap tindakannya, sehingga bila ingin menampilkan kinerja yang baik, maka dibutuhkan kecerdasan spiritual (Munir 2003, dalam Fabiola, 2005).

Kecerdasan spritual yang dimiliki setiap orang tidaklah sama. Hal tersebut tergantung dari masing-masing pribadi orang tersebut dalam memberikan makna pada hidupnya. Kecerdasan spritual lebih bersifat luas dan tidak terbatas pada 
agama saja. Perbedaan yang dimiliki masing-masing individu akan membuat kinerja yang mereka capai pun berbeda pula (Idrus, 2002).

Penelitian Mudali(2002) membuktikan tentang pentingnya kecerdasan spiritual. Seseorang haruslah memiliki SQ yang tinggi agar dia dapat benar-benar menjadi pintar. Kecerdasan tersebut juga dibutuhkan dalam dunia kerjanya, apabila ketiga kecerdasan tersebut dapat berfungsi secara efektif maka dia akan menampilkan hasil kerja yang menonjol.

Hasil penelitian Wiersma (2002) menyatakan bahwa kecerdasan spiritual mempengaruhi tujuan seseorang dalam mencapai karirnya di dunia kerja. Seseorang yang membawa makna spiritualitas dalam kerjanya akan merasakan hidup dan pekerjaannya lebih berarti. Hal ini akan memotivasi mereka agar bekerja lebih baik sehingga kinerjanya juga baik. Pada penelitian Choriyah (2013) dan Maryani dan Ludigdo (2001) yang menguji pengaruh kecerdasan spiritual dan kinerja pegawai juga menunjukkan bahwa kecerdasan spiritual memiliki pengaruh positif dan signifikan terhadap kinerja.

Berdasarkan uraian di atas maka hipotesis yang dikembangkan adalah:

H7: Kecerdasan spiritual berpengaruh positif terhadap kinerja

\section{METODE}

\section{Populasi}

Populasidalampenelitianiniadalahpegawai Biro Umum di Kantor Setda Provinsi Jawa Tengah yang berjumlah 216 orang.

\section{Sampel}

Sampel adalah sebagian dari populasi yang memiliki karakteristik yang relatif sama dan dianggap bisa mewakili populasi (Singarimbun, 1991). Untuk menentukan jumlah sampel yang akan digunakan sebagai sumber informasi dalam penelitian ini digunakan rumus Slovin (Supramono, 2004).

Berdasarkan hasil perhitungan penentuan jumlah sampel dengan rumus Slovin maka jumlah sampel minimal yang diperlukan dalam penelitian ini adalah 140 responden pegawai di Biro Umum di Kantor Setda Provinsi Jawa Tengah. Penyebaran kuesioner menggunakan teknik purposive sampling.

\section{Metode Pengumpulan Data}

Untuk mengumpulkan data penelitian, kuesioner dipilih sebagai metode pengumpulan data dalam penelitian ini. Tipe pertanyaan dalam kuesioner adalah pertanyaan tertutup dimana responden diminta untuk membuat pilihan diantara serangkaian alternatif yang diberikan oleh peneliti (Sekaran, 2006). Adapun skala jawaban yang disediakan adalah $1 \mathrm{~s} / \mathrm{d} 7$.

\section{Teknik Analisis}

Metode regresi yang digunakan dalam penelitian ini terdiri dari Uji Regresi Berganda. Uji Regresi berganda ini dikembangkan untuk mengestimasi nilai 
variabel dependen (Y) dengan menggunakan lebih dari satu variabel independen (X).

\section{HASIL DAN PEMBAHASAN}

\section{Persamaan Regresi Berganda untuk Persamaan Pertama}

Berdasarkan hasil pengujian yang dilakukan terhadap variabel kecerdasan emosional, kecerdasan intelektual, dan kecerdasan spiritual maka dapat dirumuskan persamaan regresi bergandanya sebagai berikut :

$Y_{1}=0,221 X_{1}+0,190 X_{2}+0,492 X_{3}$

Dimana :

$\mathrm{Y}_{1} \quad=$ Sikap etis

$\mathrm{X}_{1} \quad=$ Kecerdasan emosional

$\mathrm{X}_{2} \quad=$ Kecerdasan intelektual

$\mathrm{X}_{3} \quad=$ Kecerdasan spiritual

Dengan menggunakan persamaan regresi pada model regresi berganda di atas maka dapat diuraikan sebagai berikut :

a. $\beta_{1}=0,221$

$\beta_{1}$ bertanda positif menunjukkan besarnya pengaruh kecerdasan emosional terhadap sikap etis yang berarti bahwa bila kecerdasan emosional semakin tinggi maka akan meningkatkan sikap etis pegawai.

b. $\beta_{2}=0,190$

$\beta_{2}$ bertanda positif menunjukkan besarnya pengaruh kecerdasan intelektual terhadap sikap etis yang berarti bahwa bila kecerdasan intelektual semakin tinggi maka akan meningkatkan sikap etis pegawai.

c. $\beta_{3}=0,492$

$\beta_{3}$ bertanda positif menunjukkan besarnya pengaruh kecerdasan spiritual terhadap sikap etis yang berarti bahwa bila kecerdasan spiritual semakin tinggi maka akan meningkatkan sikap etis pegawai.

Berdasarkan hasil pengujian yang dilakukan pada variabel kecerdasan emosional, kecerdasan intelektual, dan kecerdasan spiritual terhadap sikap etis dapat diketahui bahwa kecerdasan spiritual dengan koefisien regresi sebesar 0,492 merupakan variabel yang memiliki pengaruh dominan atau paling besar terhadap sikap etis pegawai.

\section{Uji Signifikansi Parsial(Uji t) Persamaan Pertama}

Pengujian terhadap kedua hipotesis yang diajukan dalam penelitian ini dilakukan dengan menggunakan Uji tdengan kriteria sebagai berikut :

a. Jika nilai $\mathrm{t}$ hitung $>\mathrm{t}$ tabel pada df $(\mathrm{n}-1=139$ dan $\alpha=5 \%)=1,977$ atau nilai signifikansi < 0,05 maka dapat disimpulkan bahwa variabel independen terbukti secara statistik berpengaruh terhadap variabel dependen

b. Jika nilai t hitung $<\mathrm{t}$ tabel pada df $(\mathrm{n}-1=139$ dan $\alpha=5 \%)=1,977$ atau nilai signifikansi > 0,05 maka dapat disimpulkan bahwa variabel independen tidak terbukti secara statistik berpengaruh terhadap variabel dependen 
Adapun hasil pengujiannya disajikan dalam Tabel 1 berikut ini.

Tabel 1

Hasil Uji Hipotesis Persamaan Pertama

Coefficients $^{\mathrm{a}}$

\begin{tabular}{|c|c|c|c|c|c|c|}
\hline \multirow{2}{*}{\multicolumn{2}{|c|}{ Model }} & \multicolumn{2}{|c|}{$\begin{array}{l}\text { Unstandardized } \\
\text { Coefficients }\end{array}$} & $\begin{array}{l}\text { Standardized } \\
\text { Coefficients }\end{array}$ & \multirow[t]{2}{*}{$\mathrm{t}$} & \multirow[t]{2}{*}{ Sig. } \\
\hline & & \begin{tabular}{|l|l}
$\mathrm{B}$ & \\
\end{tabular} & Std. Error & Beta & & \\
\hline & (Constant) & 2,306 & 2,523 & & ,914 & ,362 \\
\hline & Keceerdasan Emosional &, 361 &, 105 & ,221 & 3,423 & ,001 \\
\hline & Kecerdasan Intelektual & ,459 & ,171 & , 190 & 2,677 &, 008 \\
\hline & Kecerdasan Spiritual & ,542 & 081 & ,492 & 6,691 & 000 \\
\hline
\end{tabular}

a. Dependent Variable: Sikap Etis

Sumber : Data primer yang diolah, 2015

Mengacu pada output SPSS di atas maka dapat dilakukan pengujian atas hipotesis penelitian sebagai berikut:

Pengujian ada tidaknya pengaruh kecerdasan emosional, intelektual dan spiritual terhadap sikap etis yang menghasilkan nilai signifikansi $<0,05$ maka dapat disimpulkan bahwa kecerdasan emosional, intelektual, dan spiritual masingmasing terbukti berpengaruh positif signifikan terhadap sikap etis.

\section{Persamaan Regresi Berganda untuk Persamaan Kedua}

Berdasarkan hasil pengujian yang dilakukan terhadap variabel kecerdasan emosional, kecerdasan intelektual, kecerdasan spiritual, dan sikap etis maka dapat dirumuskan persamaan regresi bergandanya sebagai berikut :

$Y_{2}=0,121 X_{1}+0,119 X_{2}+0,143 X_{3}+0,625 Y_{1}$

Dimana :

$\mathrm{Y}_{2} \quad=$ Kinerja pegawai

$\mathrm{Y}_{1}=$ Sikap etis

$\mathrm{X}_{1} \quad=$ Kecerdasan emosional

$$
\begin{array}{cc}
\mathrm{X}_{2} & =\text { Kecerdasan intelektual } \\
\mathrm{X}_{3} & =\text { Kecerdasan spiritual }
\end{array}
$$

Dengan menggunakan persamaan regresi pada model regresi berganda di atas maka dapat diuraikan sebagai berikut :

a. $\beta_{4}=0,121$

$\beta_{4}$ bertanda positif menunjukkan besarnya pengaruh kecerdasan emosional terhadap kinerja pegawai yang berarti bahwa bila kecerdasan emosional semakin tinggi maka akan meningkatkan kinerja pegawai.

b. $\beta_{5}=0,119$

$\beta_{5}$ bertanda positif menunjukkan besarnya pengaruh kecerdasan intelektual terhadap kinerja pegawai yang berarti bahwa bila kecerdasan intelektual semakin tinggi maka akan meningkatkan kinerja pegawai.

c. $\beta_{6}=0,143$

$\beta_{6}$ bertanda positif menunjukkan besarnya pengaruh kecerdasan spiritual terhadap kinerja pegawai yang berarti bahwa bila kecerdasan spiritual semakin tinggi maka akan meningkatkan kinerja pegawai. 


\section{d. $\quad \beta_{7}=0,625$}

$\beta_{7}$ bertanda positif menunjukkan besarnya pengaruh sikap etis terhadap kinerja pegawai yang berarti bahwa bila sikap etis semakin tinggi maka akan meningkatkan kinerja pegawai.

Berdasarkan hasil pengujian yang dilakukan pada variabel kecerdasan emosional, kecerdasan intelektual, kecerdasan spiritual, dan sikap etis terhadap kinerja pegawai dapat diketahui bahwa sikap etis dengan koefisien regresi sebesar 0,625 merupakan variabel yang memiliki pengaruh dominan atau paling besar terhadap kinerja pegawai.

\section{Uji Signifikansi Parsial (Uji t) Persamaan Pertama}

Pengujian terhadap kedua hipotesis yang diajukan dalam penelitian ini dilakukan dengan menggunakan Uji tdengan kriteria sebagai berikut :

a. Jika nilai t hitung $>\mathrm{t}$ tabel pada df $(\mathrm{n}-1=139$ dan $\alpha=5 \%)=1,977$ atau nilai signifikansi $<0,05$ maka dapat disimpulkan bahwa variabel independen terbukti secara statistik berpengaruh terhadap variabel dependen

b. Jika nilai t hitung $<\mathrm{t}$ tabel pada df $(\mathrm{n}-1=139$ dan $\alpha=5 \%)=1,977$ atau nilai signifikansi > 0,05 maka dapat disimpulkan bahwa variabel independen tidak terbukti secara statistik berpengaruh terhadap variabel dependen

Adapun hasil pengujiannya disajikan dalam Tabel 4 berikut ini.

Tabel 4

\section{Hasil Uji Hipotesis Persamaan Kedua}

Coefficients $^{\mathrm{a}}$

\begin{tabular}{|c|c|c|c|c|c|}
\hline \multirow[t]{2}{*}{ Model } & \multicolumn{2}{|c|}{$\begin{array}{c}\text { Unstandardized } \\
\text { Coefficients }\end{array}$} & $\begin{array}{c}\text { Standardized } \\
\text { Coefficients }\end{array}$ & \multirow[t]{2}{*}{$\mathrm{t}$} & \multirow[t]{2}{*}{ Sig. } \\
\hline & B & Std. Error & Beta & & \\
\hline (Constant) &,- 464 & 1,868 & &,- 248 & ,804 \\
\hline Keceerdasan Emosional & ,201 & ,081 &, 121 & 2,481 & ,014 \\
\hline 1 Kecerdasan Intelektual & ,292 &, 130 & , 119 & 2,253 & ,026 \\
\hline Kecerdasan Spiritual &, 161 & ,069 &, 143 & 2,331 & 021 \\
\hline Sikap Etis & ,639 & ,063 & ,625 & 10,102 &, 000 \\
\hline
\end{tabular}

a. Dependent Variable: Kinerja Pegawai

Sumber : Data primer yang diolah, 2015

Pengujian ada tidaknya pengaruh kecerdasan emosional, intelektual, spiritual, dan sikap etis terhadap kinerja pegawai yang menghasilkan nilai signifikansi $<0,05$ maka dapat disimpulkan bahwa kecerdasan emosional, intelektual, spiritual, dan sikap etis masing-masing terbukti berpengaruh positif signifikan terhadap kinerja pegawai.

\section{Uji Kelayakan Model Persamaan Pertama}

Uji kelayakan model dilakukan untuk mengetahui apakah variabel-variabel yang diteliti dalam penelitian ini memiliki tingkat kelayakan yang tinggi untuk dapat menjelaskan fenomena yang dianalisis. Pengujian kelayakan model 
dilakukan dengan menggunakan Uji F, dimana hasilnya disajikan dalam Tabel 3 berikut

ini.

Tabel 3

Hasil Pengujian Kelayakan Model Persamaan Pertama

\begin{tabular}{|c|c|c|c|c|c|c|}
\hline & \multicolumn{6}{|c|}{ ANOVA $^{\mathrm{a}}$} \\
\hline & Model & Sum of Squares & \begin{tabular}{l|l}
$\mathrm{df}$ & \\
\end{tabular} & Mean Square & $\mathrm{F}$ & Sig. \\
\hline & Regression & 10083,363 & 3 & 3361,121 & 64,516 &, $000^{b}$ \\
\hline 1 & Residual & 7085,237 & 136 & 52,097 & & \\
\hline & Total & 17168,600 & 139 & & & \\
\hline
\end{tabular}

a. Dependent Variable: Sikap Etis

b. Predictors: (Constant), Kecerdasan Spiritual, Keceerdasan Emosional, Kecerdasan Intelektual Sumber : Data primer yang diolah, 2015

Pengujian kelayakan model dilakukan dengan menganalisis nilai signifikansi dari Uji F yaitu sebesar 0,000 yang kurang dari $\alpha(0,05)$. Hal ini menunjukkan bahwa variabel independen yang digunakan, yaitu kecerdasan emosional, kecerdasan intelektual, dan kecerdasan spiritual merupakan variabel yang tepat/layak untuk menjelaskan terjadinya variasi dalam variabel sikap etis.

\section{KoefisienDeterminasiPersamaanKedua}

Tabel 5

Hasil Analisis Koefisien Determinasi Persamaan Kedua

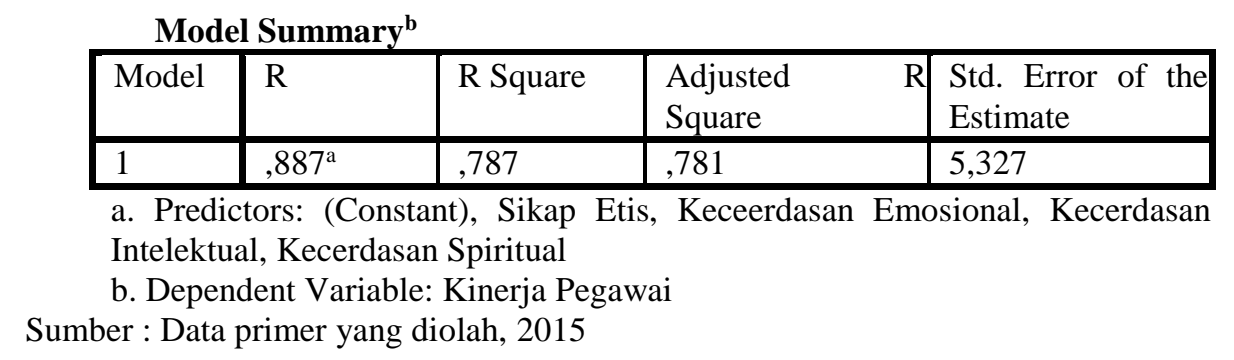

Koefisien determinasi yang digunakan dalam penelitian ini adalah nilai Adjusted R Square yaitu sebesar 0,781 atau sebesar 78,1\%. Hal ini menunjukkan bahwa variabel independen (kecerdasan emosional, kecerdasan intelektual, kecerdasan spiritual, dan sikap etis) mampu menjelaskan variasi yang terjadi pada kinerja pegawai sebesar $78,1 \%$.

\section{Koefisien Determinasi Total}

Berdasarkan hasil perhitungan nilai koefisien determinasi pada persamaan pertama dan kedua maka dapat ditentukan pula nilai koefisien determinasi total.

a. Error term

$$
\begin{aligned}
& \mathrm{e} 1=\sqrt{1-R 1^{2}}=\sqrt{1-0,587^{2}}=\sqrt{1-0,344}=0,809 \\
& \mathrm{e} 2=\sqrt{1-R 2^{2}}=\sqrt{1-0,787^{2}}=\sqrt{1-0,619}=0,617
\end{aligned}
$$


b. Koefisien Determinasi Total

$\mathrm{R} 2 \mathrm{M}=1-(\mathrm{e} 1)^{2}(\mathrm{e} 2)^{2}=1-\left((0,809)^{2}(0,617)^{2}\right)=1-((0,654)(0,381))$

$=1-0,249=0,751=75,1 \%$

\section{Uji Kelayakan Model Persamaan Kedua}

Uji kelayakan model dilakukan untuk mengetahui apakah variabel-variabel yang diteliti dalam penelitian ini memiliki tingkat kelayakan yang tinggi untuk dapat menjelaskan fenomena yang dianalisis. Pengujian kelayakan model dilakukan dengan menggunakan Uji F, dimana hasilnya disajikan dalam Tabel 6 berikut

ini.

\section{Tabel 6}

Hasil Pengujian Kelayakan Model Persamaan Kedua

\begin{tabular}{|c|c|c|c|c|c|c|}
\hline \multicolumn{7}{|c|}{ ANOVA $^{a}$} \\
\hline & Model & Sum of Squares & df & Mean Square & $\mathrm{F}$ & Sig. \\
\hline & Regression & 14157,807 & 4 & 3539,452 & 124,722 &, $000^{\mathrm{b}}$ \\
\hline 1 & Residual & 3831,129 & 135 & 28,379 & & \\
\hline & Total & 17988,936 & 139 & & & \\
\hline
\end{tabular}

a. Dependent Variable: Kinerja Pegawai

b. Predictors: (Constant), Sikap Etis, Keceerdasan Emosional, Kecerdasan Intelektual, Kecerdasan Spiritual

Sumber : Data primer yang diolah, 2015

Pengujian kelayakan model dilakukan dengan menganalisis nilai signifikansi dari Uji F yaitu sebesar 0,000 yang kurang dari $\alpha(0,05)$. Hal ini menunjukkan bahwa variabel independen yang digunakan, yaitu kecerdasan emosional, kecerdasan intelektual, kecerdasan spiritual, dan sikap etis merupakan variabel yang tepat/layak untuk menjelaskan terjadinya variasi dalam variabel kinerja pegawai.

\section{PENUTUP.}

\section{Kesimpulan}

Mengacu pada hasil penelitian dan tujuan dari penelitian ini maka terdapat tiga yang dapat disimpulkan dari penelitian ini, yaitu: 1) Pengujian pada variabel kecerdasan emosional dan sikap etis PNS menunjukkan bahwa secara statistik kecerdasan emosional terbukti berpengaruh signifikan terhadap sikap etis PNS di lingkungan Biro Umum di Kantor Setda Provinsi Jawa Tengah 2) Pengujian pada variabel kecerdasan intelektual dan sikap etis PNS menunjukkan bahwa secara statistik kecerdasan intelektual terbukti berpengaruh signifikan terhadap sikap etis PNS di lingkungan Biro Umum di Kantor Setda Provinsi Jawa Tengah; 3) Pengujian pada variabel kecerdasan spiritual dan sikap etis PNS menunjukkan bahwa secara statistik kecerdasan spiritual terbukti berpengaruh signifikan terhadap sikap etis PNS di lingkungan Biro Umum di Kantor Setda Provinsi Jawa Tengah; 4) Pengujian pada variabel sikap etis PNS dan kinerja pegawai menunjukkan bahwa secara statistik sikap etis PNS terbukti berpengaruh signifikan terhadap kinerja PNS di lingkungan Biro Umum di Kantor Setda 
Provinsi Jawa Tengah; 5) Pengujian pada variabel kecerdasan emosional dan kinerja PNS menunjukkan bahwa secara statistik kecerdasan emosional terbukti berpengaruh signifikan terhadap kinerja PNS di lingkungan Biro Umum di Kantor Setda Provinsi Jawa Tengah; 6) Pengujian pada variabel kecerdasan intelektual dan kinerja PNS menunjukkan bahwa secara statistik kecerdasan intelektual terbukti berpengaruh signifikan terhadap kinerja PNS di lingkungan Biro Umum di Kantor Setda Provinsi Jawa Tengah; 7)pengujian pada variabel kecerdasan spiritual dan kinerja PNS menunjukkan bahwa secara statistik kecerdasan spiritual terbukti berpengaruh signifikan terhadap kinerja PNS di lingkungan Biro Umum di Kantor Setda Provinsi Jawa Tengah.

\section{Implikasi Teoritis}

Hipotesis yang dikembangkan dalam penelitian ini didasarkan pada berbagai teori dan hasil-hasil penelitian terdahulu. Oleh sebab itu, hasil penelitian ini berimplikasi pada teori dan hasil penelitian yang mendasarinya. Adapun implikasi teoritis dari penelitian ini adalah sebagai berikut: 1) Hasil uji statistik menunjukkan bahwa kecerdasan emosional terbukti berpengaruh signifikan terhadap sikap etis PNS di lingkungan Biro Umum di Kantor Setda Provinsi Jawa Tengah. Hasil penelitian ini sejalan dengan hasil penelitian yang telah dilakukan oleh Maryani dan Ludigdo (2001), Jamaluddin dan Indriasari (2012), Lucyanda dan Eko (2013) juga membuktikan pengaruh positif dan signifikan dari kecerdasan emosional terhadap sikap etis; 2) Hasil uji statistik menunjukkan bahwa kecerdasan intelektual terbukti berpengaruh signifikan terhadap sikap etis PNS di lingkungan Biro Umum di Kantor Setda Provinsi Jawa Tengah. Hasil penelitian ini tidak berbeda dengan penelitian yang telah dilakukan oleh Tikollah, dkk (2006), Maryani dan Ludigdo (2001), Jamaluddin dan Indriasari (2012) menunjukkan bahwa kecerdasan intelektual terbukti berpengaruh positif signifikan terhadap sikap etis; 3) Hasil uji statistik menunjukkan bahwa kecerdasan spiritual terbukti berpengaruh signifikan terhadap sikap etis PNS di lingkungan Biro Umum di Kantor Setda Provinsi Jawa Tengah. Penelitian terdahulu dari Maryani dan Ludigdo (2001), Ika (2011), Jamaluddin dan Indriasari (2012), Ramly, Chai dan Lung (2008) juga membuktikan pengaruh positif dan signifikan dari kecerdasan spiritual terhadap sikap etis; 4) Hasil uji statistik menunjukkan bahwa sikap etis PNS terbukti berpengaruh signifikan terhadap kinerja PNS di lingkungan Biro Umum di Kantor Setda Provinsi Jawa Tengah. Penelitian Choriyah (2013) pada variabel sikap etis dan kinerja juga menunjukkan bahwa sikap etis terbukti berpengaruh positif dan signifikan terhadap kinerja; 5) Hasil uji statistik menunjukkan bahwa kecerdasan emosional terbukti berpengaruh signifikan terhadap kinerja PNS di lingkungan Biro Umum di Kantor Setda Provinsi Jawa Tengah. Demikian pula dengan penelitian yang telah dilakukan oleh Choriyah (2013), Agustian (2001) pada variabel kecerdasan emosional dan kinerja menunjukkan bahwa kecerdasan emosional memiliki pengaruh positif dan signifikan terhadap kinerja; 6) Hasil uji statistik menunjukkan bahwa kecerdasan intelektual terbukti berpengaruh signifikan terhadap kinerja PNS di lingkungan Biro Umum di Kantor Setda Provinsi Jawa Tengah.Penelitian yang dilakukan oleh Wiramiharja (2003), Choriyah (2013) dan Moustafa dan Miller (2003) juga 
menemukan bahwa kecerdasan yang lebih bersifat kognitif berpengaruh signifikan terhadap kinerja karyawan; 7) Hasil uji statistik menunjukkan bahwa kecerdasan spiritual terbukti berpengaruh signifikan terhadap kinerja PNS di lingkungan Biro Umum di Kantor Setda Provinsi Jawa Tengah. Demikian pula dengan studi dari Hasil penelitian Wiersma (2002), Choriyah (2013) dan Mudali(2002) menyatakan bahwa kecerdasan spiritual mempengaruhi tujuan seseorang dalam mencapai karirnya di dunia kerja.

\section{Keterbatasan dan agenda Penelitian}

Nilai R Square Total yang dihasilkan dalam penelitian ini adalah sebesar $75,1 \%$ artinya masih terdapat 24,9 variabel lain yang dapat menjelaskan kinerja pegawai yang belum diteliti dalam penelitian ini. Berangkat dari keterbatasan yang ditemukan dalam penelitian ini maka dalam penelitian mendatang dapat menambahkan variabel lain, seperti religiusitas untuk dimasukkan dalam model penelitian dan diuji pengaruhnya terhadap sikap etis pegawai.

\section{DAFTAR PUSTAKA}

Abdulrahim, A (1999), Pengaruh Perbedaan Gender terhadap Perilaku Akuntan Pendidik, Tesis, Program Pascasarjana Universitas Gadjah Mada, Yogyakarta.

Agustian, Ary Ginanjar (2001), Rahasia Sukses Membangun Kecerdasan Emosi dan Spiritual (ESQ) Berdasarkan 6 Rukun Iman dan 5 Rukun Islam, Penerbit Arga, Jakarta.

Aida dan Listianingsih (2004), Pengaruh sistem pengukuran kinerja sistem reward dan profit center terhadap hubungan antara total Quality management dengan kinerja manajerial, SNA VIII, Solo.

Arie, Pangestu Dwijayanti (2009), Pengaruh Kecerdasan Emosional, Kecerdasan Intelektual, Kecerdasan Spiritual Dan Kecerdasan Sosial Terhadap Pemahaman Akuntansi. Skripsi Universitas Pembangunan Nasional "VETERAN". Jakarta.

A’sad (1995), Psikologi Industri, Liberty, Yogyakarta.

Azwar (2005), Sikap Manusia: Teori dan Pengukurannya, Pustaka Pelajar, Yogyakarta.

Baihaqi, S (2002), Analisis Pengaruh EQ Karyawan terhadap Kualitas Perilaku Pelayanan Kepada Wajib Pajak di Kantor Pelayanan PBB (Studi pada KPPBB Kediri dan Tulung Agung), Fakultas Ekonomi Universitas Gadjah Mada, Yogyakarta. 
Bernadin, H.J dan J.E.A Russel (1993), Human Resources Management, McGraw Hill, Singapore.

Carusso, D.R (1999), Applying The Ability Model Of Emotional IntelligenceTo The World Of Work, http://cjwolfe.com/article.doc, 15 Oktober 2015.

Choriyah, Anis (2013), Pengaruh Kecerdasan Emosional, Kecerdasan Intelektual, Kecerdasan Spiritual, dan Etika Profesi terhadap Kinerja Auditor dalam Kantor Akuntan Publik (Studi Empiris pada Auditor dalam Kantor Akuntan Publik di Kota Padang dan Pekanbaru), Universitas Negeri Padang.

Chrismastuti, A.A \& V. Purnamasari (2004), Hubungan Sifat Machiavellian, Pembelajaran Etika dalam Mata Kuliah Etika, dan Sikap Etis Akuntan: Suatu Analisis Perilaku Etis Akuntan dan Mahasiswa Akuntansi di Semarang, Proceeding Simposium Nasional Akuntansi VII, Denpasar, 2-3 Desember: 247-266.

Clark, J.W \& L.E Dawson (1996), Personal Religiousness and Ethical Judgement: An Empirical Analysis, Journal of Business Ethics 15, 359-372.

Dani, K (2002), Kamus Lengkap Bahasa Indonesia, Putra Harsa, Surabaya.

Depdikbud (2000), Kamus Besar Bahasa Indonesia, Balai Pustaka, Jakarta

Desmita (2006), Psikologi Perkembangan, PT Remaja Rosdakarya, Bandung.

Dessler, Gary (1997), Manajemen Sumber Daya Manusia, Indeks, Jakarta.Dwijayanti (2009)

Elhamidi (2009), Pengertian Kecerdasan Intelektual" tersed ia pada http ://elhamidy. blogspot.com/2009/06/pengert ian-kecerdasan-intelektual.html (diakses tanggal 8 Desember 2014).

Fabiola, R.A (2005), Analisis Pengaruh Kecerdasan Intelektual, Kecerdasan Emosional dan Kecerdasan Spiritual Terhadap Kinerja Karyawan (Studi kasus di hotel Horison Semarang), Tesis, Universitas Diponegoro.

Ferdinand, Augusty (2006), Structural Equation Modeling dalam Penelitian Manajemen, Fakultas Ekonomi, Universitas Diponegoro.

Ghozali, Imam (2009), Aplikasi Analisis Multivariet Dengan Program SPSS, Badan Penerbit Universitas Diponegoro, Semarang.

Ghozali, Imam (2001), Aplikasi Analisis Multivariet Dengan Program SPSS, Badan Penerbit Universitas Diponegoro, Semarang

Ginanjar, Ary Agustian (2007), Rahasis Sukses Membangun Kecerdasan Emosi dan Spiritual Berdasarkan 6 Rukun Iman dan 5 Rukun Islam, Arga, Jakarta. 
Goleman, D (2005), Kecerdasan Emosi : Mengapa Emotional Intelligence Lebih Tinggi Daripada IQ, Alih Bahasa : T. Hermay, PT. Gramedia Pustaka Utama, Jakarta

Gordon, E (2004), EQ dan Kesuksesan Kerja,Focus-online, http://www.epsikologi, com, 12 Oktober 2015.

Hadi, Sutrisno (2002), Metodologi Reset II, Fakultas Psikologi Universitas Gadjah Mada, Yogyakarta

Hasan, Iqbal (2002), Pokok-Pokok Materi Statistik 2 (Statistik Inferensif). Bumi Aksara, Jakarta.

Idrus, Muhammad (2002), Kecerdasan Spiritual Mahasiswa Yogyakarta, Psikologi Phronesis, Jurnal Ilmiah dan Terapan, Vo.4, No.8, Desember 2002

Ika, Desi (2011), Pengaruh Kecerdasan Emosional dan Spiritual terhadap Sikap Etis Mahasiswa Akuntansi dipandang dari Segi Gender (Studi pada Perguruan Tinggi Negeri di Kota Medan), Jurnal Keuangan dan Bisnis, 3 (2), 111-132.

Jamaluddin dan Rahayu Indriasari (2012), Pengaruh Kecerdasan Intelektual, Kecerdasan Emosional, Kecerdasan Spiritual terhadap Etika Mahasiswa Akuntansi Fakultas Ekonomi Universitas Tadulaku.

Joseph, G (1978), Interpreting Psychological Test Data, Vol.1, New York VNR

Keraf, A.S (1998), Etika Bisnis: Membangun Citra Bisnis sebagai Profesi Luhur, Penerbit Kanisius, Yogyakarta.

Keraf, A Sony dan R.H Imam (1995), Etika Bisnis Membangun Citra Bisnis sebagai Profesi Luhur, Yogyakarta.

Lucyanda, Jurica dan Gunardi Eko (2013), Faktor-Faktor yang Mempengaruhi Perilaku Etis Mahasiswa Akuntansi Universitas Bakrie, Media Riset Akuntansi, 2 (2).

Ludigdo, U (1999), Pengaruh Gender terhadap Etika Bisnis: Studi atas Persepsi Akuntan dan Mahasiswa Akuntansi,Proceeding Simposium Nasional Akuntansi II. Malang, 24-25 Sepetember : 1-17.

Ludigdo, Unti (2006), Strukturasi Praktik Etika di Kantor Akuntan Publik: Sebuah Studi Interpretif, Simposium Nasional Akuntansi IX, Universitas Andalas, Padang. 
Ludigdo, U dan F. Meilisa (2001), Persepsi Mahasiswa Akuntansi terhadap Etika Akuntan Pendidik di Jurusan Akuntansi Fakultas Ekonomi Universitas Brawijaya, Jurnal Akuntansi Multiparadigma, 1 (2).

Madjid, Ahmad (1992), Etika Sosial: Asas Moral dalam Kehidupan Manusia, Rineka Cipta, Jakarta.

Maryani, T dan U. Ludigdo (2001), Survei atas Faktor-faktor yang Mempengaruhi Sikap dan Perilaku Etis Akuntan,Jurnal TEMA, 2 (1): 49- 62.

Mathis dan Jackson (2002), Manajemen Sumber Daya Manusia, Salemba Empat, Jakarta.

Melandy, R dan N. Aziza (2006), Pengetahuan Kecerdasan Emosional Terhadap Pemahaman Akuntansi Kepercayaan Diri sebagai Variabel Pemoderasi,Padang: Jurnal Simposium Nasional Akuntansi IX.

Moustafa, K.S dan T.R Miller (2003), Too Intelligent For The Job ? The Validity of Upper-Limit Cognitive Ability Test Scores In Selection, Sam Advanced Management Journal, Vol. 68.

Mudali (2002), Quote : How High Is Yous Spiritual Intelligence?,http://www.eng.usf.edu/gopalakr/artcles/spiritual.html, $\quad 15$ Oktober 2015

Mulyadi (2007), Auditing, Salemba Empat, Jakarta.

Panangian, Reza (2012), Pengaruh Kecerdasan Emosional dan Kecerdasan Spiritual Terhadap Tingkat Pemahaman Akuntansi, Sekolah Tinggi Ilmu Ekonomi Perbanas, Surabaya.

Pratiwi \& Asih (2011), Perilaku Prososial ditinjau dari Empati dan Kematangan Emosi, Jurnal Psikologi, 1 (1).

Purba, Ahmad (1999), Emotional Intelligence, Seri Ayah Bunda, 26 Juli-8 Agustus, Dian Raya, Jakarta.

Purwanto, Didik. Ernawati (2010), Pengaruh Kompetensi, Kecerdasan Emosional dan Efikasi Diri Terhadap Kenyamanan Pimpinan Dalam Melakukan Penilaian Kinerja Karyawan, Jurnal Ekonomi dan Kewirausahaan, 10 (1) h: 74-82

Rachmi, Filia (2010), Pengaruh Kecerdasan Emosional, Kecerdasan Spiritual, dan Perilaku Belajar terhadap Pemahaman Akuntansi, Fakultas Ekonomi, Universitas Diponegoro, Semarang.

Ramly, Z., L.T Chai dan C.K Lung (2008), Religiosity as A Predictor of Consumer Ethical Behavior: Some Evidence from Young Consumers from 
Malaysia, Journal of Business Systems, Governance and Ethics, 3 (4), 4356.

Reiss, M.C \& K. Mitra (1998), The Effects of Individual Difference Factors on the Acceptability of Ethical and Unethical Workplace Behaviors, Journal of Business Ethics, 17 (14), 1581-1593.

Ruegger, D \& E.W King (1992), A Study Of The Effect Of Age And Gender Upon Student Business Ethics, Journal of Business Ethics, 11, 179-186.

Sekaran, Uma (2006), Research Methods for Business: A Skill Building Approach, John Wiley \& Sons Inc, New York.

Singarimbun, M \& Effendi (1991), Metode Penelitian Survey, Penerbit PT. Pustaka LP3ES Indonesia, Jakarta.

Soeparwoto (2005), Psikologi Perkembangan, UPT UNNES PRESS, Semarang.

Sugiyono (2003), Statistika untuk Penelitian, Penerbut Alfabeta, Bandung.

Supramono dan Intiyas Utami (2004), Desain Proposal Penelitian Akuntansi \& Keuangan, Penerbit Andi, Yogyakarta.

Svyantek, D.J (2003), Emotional Intellegence and Organizational Behavior, The International Journal of Organizational Analysis, 11, 167-169.

Tikollah, dkk (2006), Pengaruh Kecerdasan Intelektual, Kecerdasan Emosional, dan Kecerdasan Spiritual terhadap Sikap Etis Mahasiswa Akuntansi (Studi Pada Perguruan Tinggi Negeri di Kota Makasar Provinsi Sulawesi Selatan), Simposium Nasional Akuntansi 9, Padang.

Trihandini, R.A Fabiola Meirnayati (2005), Analisis Pengaruh Kecerdasan Intelektual, Kecerdasan Emosional, dan Kecerdasan Spiritual terhadap Kinerja Karyawan: Studi kasus di Hotel Horizon, Semarang, Tesis pada Program Magister Manajemen Universitas Diponegoro, Semarang.

Tyson, T (1992), Does Believing that Everyone Else is Less Ethical have an Impact on Work Behavior?, Journal of Business Ethics, 11, 707-717.

Verbeke, W., C. Ouwerkerk \& E. Peelen (1996), Exploring the Contextual and Individual Factors on Ethical Decision Making of Salespeople,Journal of Business Ethics, 15, 1175-1187.

Weaver, G.R \& B.R Agle (2002), Religiosity and Ethical Behavior in Organizations: A Symbolic Interactionist Perpective, Academy of Management Review, 27 (1), 77-97. 
Widagdo et al (2002), Analisis Pengaruh Atribut -Atribut Kualitas Audit Terhadap Kepuasan Klien, Simposium Nasional Akuntansi 5. 560-574.

Wiersma, M.L (2002), The Influence of Spiritual "Meaning-Making" On Career Behaviour, Journal of Management Development, Vo.21, No.7, pp.497-520

Wimbush, J.C., J.M Shepard \& S.E Markham (1997), An Empirical Examination of the Relationship between Ethical Climate and Ethical Behavior from Multiple Levels of Analysis,Journal of Business Ethics, 16, 1705-1716.

Winardi (1996), Perilaku Konsumen, Bandung.

Wiramiharja, A Sutardo (2003), Pengantar Psikologi Abnormal, Rendika Aditama, Bandung.

Yani, Fitri (2011), Pengaruh Kecerdasan Intelektual, Kecerdasan Emosional, Kecerdasan Spiritual Terhadap Pemahaman Akuntansi, Jurnal Akuntansi Pendidikan, Universitas Riau.

Zohar, D dan I Marshall (2002), SQ (Spiritual Intelligence) : The Ultimate Intelligence, Blomsburry Publishing, London

Zohar, D dan I. Marshall (2005), Spiritual Capital,Wealth We Can Live By Using Our Rational Emotional And Spiritual Intelligence To Transform Ourselves And Corporate Culture, alih bahasa Helmi Mustofa, Bandung:Mizan Media Utama 